\title{
Evaluation of Enterococcus faecalis, Staphylococcus warneri and Staphylococcus aureus species in adults with generalized chronic periodontitis
}

\author{
Avaliação das espécies Enterococcus faecalis, Staphylococcus warneri e Staphylococcus aureus em adultos com \\ periodontite crônica generalizada
}

Aretuza FRITOLI ${ }^{1}$

Eduardo LOBÃO'

Geisla Soares ${ }^{1}$

Belén RETAMAL-VALDES'

Magda FERES ${ }^{1}$

\section{ABSTRACT}

Objective

To identify and quantify the levels of three bacterial species that have recently been identified as potential "new" periodontal pathogens (Enterococcus faecalis, Staphylococcus aureus and Staphylococcus warneri) in subjects with periodontal health and generalized chronic periodontitis.

\section{Methods}

Thirty adults with generalized chronic periodontitis and 10 periodontally healthy were included in this study. Nine subgingival biofilm samples were collected per subject and individually analyzed by checkerboard DNA-DNA hybridization technique.

\section{Results}

The mean levels of $E$. faecalis and S. warneri were higher in chronic periodontitis than in periodontal health $(p<0.05)$. Furthermore, a higher percentage of subjects with periodontitis were colonized by the three species evaluated in comparison with healthy subjects ( $p<0.05)$. This represented a difference of 40 percentage points between the two groups, for E. faecalis (present in $90 \%$ of individuals with periodontitis and $50 \%$ of the healthy individuals) and S. warneri (100\% and 60\%, respectively), and 26 percentage points for S. aureus (86\% and $60 \%$, respectively).

\section{Conclusion}

E. faecalis and S. warneri have the potential to be periodontal pathogens. The role of S. aureus was less evident, since this species was more prevalent and at relatively higher levels in health than the other two species. These data might guide future studies on the role of these microorganisms in the etiology of periodontitis and help to establish more effective treatments for these infections.

Indexing term: Chronic periodontitis. Microbiota. Noxae. Periodontal diseases.

\section{RESUMO}

\section{Objetivo}

Identificar e quantificar os níveis de três espécies bacterianas que foram recentemente apontadas como possíveis "novos" patógenos periodontais (Enterococcus faecalis, Staphylococcus warneri e Staphylococcus aureus), em indivíduos periodontalmente saudáveis e com periodontite crônica generalizada.

\section{Métodos}

A amostra foi composta por 30 indivíduos adultos com periodontite crônica generalizada e 10 periodontalmente saudáveis. Nove amostras de biofilme subgengival foram coletadas por indivíduo e analisadas individualmente pela técnica de checkerboard DNA-DNA hybridization.

\section{Resultados}

Os níveis médios de $E$. faecalis e $S$. warneri foram maiores no grupo com periodontite crônica do que no de saúde periodontal ( $p<0,05$ ). Além disso, um maior percentual de indivíduos com periodontite estavam colonizados pelas três espécies avaliadas em comparação com os indivíduos saudáveis $(p<0,05)$. Essa diferença entre os dois grupos foi de 40 pontos percentuais para $E$. faecalis (presente em $90 \%$ dos indivíduos com periodontite e $50 \%$ dos saudáveis) e S. warneri (100\% e 60\%, respectivamente), e de 26 pontos percentuais para S. aureus (86\% e $60 \%$, respectivamente).

\section{Conclusão}

E. faecalis e S. warneri tem potencial para serem patógenos periodontais. O papel do S. aureus foi menos evidente, uma vez que esta espécie estava mais prevalente e em níveis relativamente mais altos do que as outras duas espécies em saúde. Estes dados podem guiar futuros estudos sobre o papel dessas espécies na etiologia das periodontites e ajudar a estabelecer tratamentos mais eficazes para essas infecções.

Termos de indexação: Periodontite crônica. Microbiota. Noxas. Doenças periodontais.

\footnotetext{
${ }^{1}$ Universidade Guarulhos, Centro de Pós-Graduação e Pesquisa. Praça Tereza Cristina, 229, Centro, 07023-070, Guarulhos, SP, Brasil. Correspondência para / Correspondence to: M FERES. E-mail: <mferes@ung.br>.
} 


\section{INTRODUCTION}

Oral bacteria are responsible for the onset and progression of periodontal diseases. Present knowledge about the microbial etiology of periodontal diseases has been strongly based on the 40 bacterial species that have traditionally been analyzed by checkerboard DNA-DNA hybridization ${ }^{1-2}$, and that comprise the "microbial complexes of subgingival plaque" ${ }^{3}$. Studies have demonstrated that certain species, including Aggregatibacter actinomicentencomitans, Porphyromonas gingivalis and Tannerella forsythia are determinant in the occurrence of periodontal diseases and these species are considered periodontal pathogens ${ }^{4}$. However, in spite of all the advancement in knowledge about periodontal pathogens, more recent studies using molecular biology techniques considered open-ended (that seek to identify the entire content of subgingival biofilm) have shown that over 300 bacterial species may colonize the subgingival environment ${ }^{5}$. Many of these species have been suggested to be potential periodontal pathogens, including Porphyromonas endodontalis, Filifactor alocis, Enterococcus faecalis, Staphylococcus warneri, Staphylococcus aureus, Prevotella tannerae, Selenomonas sputigena, Dialister pneumosintes, Atopobium parvulum, Prevotella oris, Prevotella denticola and Archaea species ${ }^{6-10}$, among others.

In spite of the above-mentioned studies having suggested a possible pathogenic role of novel microorganisms in the etiology of periodontal disease, the majority of these presented certain limitations, particularly in relation to the number of plaque samples evaluated. Furthermore, there is still great scarcity of quantitative data (not only presence or absence) that reveal the true levels of these species in periodontal health and disease. These data are crucial for determining the real role of these species in the onset and progression of these infections ${ }^{11}$.

A more detailed analysis of some of these species in periodontally healthy patients, or those with periodontitis may help to make a more precise diagnosis of these infections, and consequently contribute to the development of more effective preventive and therapeutic protocols.

E. faecalis and S. aureus have been pointed out as being possible periodontal pathogens in previous studies ${ }^{10,12-13}$, and S. warneri was recently associated with the etiology of peri-implantitis ${ }^{14}$. However, studies of this type are still scarce, and in general, they do not evaluate sites in different categories of pockets. Therefore, new studies of association that evaluate the role of these species in periodontal health and disease may help to advance knowledge in this area. Therefore, the aim of this study was to evaluate the presence and levels of $E$. faecalis, S.warneri, S.aureus in subgingival biofilm samples of individual sites of subjects with generalized chronic periodontitis, or periodontally healthy subjects, by using the checkerboard DNA-DNA hybridization technique.

\section{METHODS}

This cross-sectional clinical study evaluated 30 volunteers with generalized chronic periodontitis, and 10 periodontally healthy subjects who sought dental attendance at Guarulhos University (UNG, SP, Brazil). The eligible individuals were informed about the nature, potential risks and benefits of their participation in the study, and were invited to sign the Term of Free and Informed Consent, containing the guidelines of the research. A copy of the document was delivered to each participant. The study protocol received the approval of the Research Ethics Committee of Guarulhos University (Protocol No. ${ }^{\circ} 437.155$ ), and was conducted in compliance with all the requisites of the Guidelines and Regulatory Norms of Researches involving human beings (Resolution 196/96 of 13/06/1996).

\section{Inclusion and exclusion criteria}

The inclusion criteria for periodontally healthy individuals were as follows: $\geq 24$ teeth, absence of sites with pocket depth (PD) and clinical attachment level (CAL) $\geq 3 \mathrm{~mm}$ and less than $20 \%$ of sites with gingival bleeding and/or bleeding on probing (BOP). The inclusion criteria for individuals with generalized chronic periodontitis were based on the latest classification of the American Academy of Periodontology ${ }^{15}: \geq 20$ teeth, $\geq 8$ sites in different teeth with $\mathrm{PD} \geq 5 \mathrm{~mm}, \mathrm{CAL} \geq 3 \mathrm{~mm}$ and $\mathrm{BOP}$; and who, a the time of attendance, presented good systemic health.

The exclusion criteria were: smokers $(\geq 10$ cigarettes/day for $\geq 5$ years $)^{16}$, ex-smokers ( $\geq 5$ years $)^{17}$, pregnant women or nursing mothers, history of periodontal treatment in the last six months, continuous use of oral antiseptics, use of systemic antibiotics, corticosteroids, non steroid anti-inflammatory agents, immunosuppressive agents, estrogen and estrogen receptor modulators and any medications that may influence bone metabolism (alendronate, calcitonin and others) in the last six months, systemic disease that may change the host response (e.g. 
diabetes) or those who require prophylactic medication for dental treatment (e.g. Mitral valve prolapse), use of orthodontic appliance and extensive prosthetic rehabilitations.

\section{Clinical examination}

Plaque index $(\mathrm{PI})$ - 0/1, gingival bleeding (GB) 0/1, bleeding on probing (BOP) - 0/1, suppuration (SUP) - 0/1, PD - mm, CAL - mm, measured in 6 sites per tooth (mesio-vestibular, buccal, disto-vestibular, disto-lingual, lingual and mesio-lingual) in all the teeth, excluding third molars. For PD and CAL evaluation, a periodontal probe of the North Carolina type (Hu-Friedy, Chicago, IL, USA) was used.

\section{Microbiological evaluation}

\section{Selection of test sites}

Nine sites were selected per each volunteer with chronic periodontitis, localized on the interproximal surfaces of non-contiguous teeth, and preferentially distributed among the four quadrants, according to the initial PD in the following categories (3 sites per category): shallow (PD $\leq 3 \mathrm{~mm}$ ), intermediate (PD 4-6 mm), and deep $(P D \geq 7 \mathrm{~mm})$. Sites localized in teeth with poorly adapted dental prostheses, extensive caries lesions and/or endoperiodontal lesions were not used. In periodontally healthy individuals, samples were collected from nine subgingival sites with initial $\mathrm{PD} \leq 3 \mathrm{~mm}$ and absence of $\mathrm{BOP}$, randomly chosen by means of an electronic program (http://www. stat.ubc.ca/rollin/stats/ssize/n2.html).

\section{Subgingival biofilm sample collection}

After the clinical exam and removal of calculus and supragingival biofilm, the subgingival biofilm samples were collected with sterilized 11-12 minifive Gracey curettes, positioned in the most apical portion of the sites, performed in a single scraping movement in the apicalcoronal direction. The samples were immediately deposited in individual plastic microtubes containing $150 \mu \mathrm{L}$ of buffer solution TE (10 mM Tris-HCL) (Invitrogen Life Technologies, Carlsbad, CA, USA), 1 mM EDTA (Labsynth Produtos para

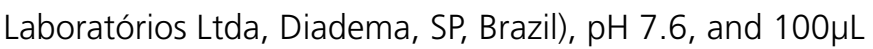
$\mathrm{NaOH}$ (Labsynth) at $0.5 \mathrm{M}$ were added to maintain the integrity of the bacterial DNA until the time of laboratory analysis. These plastic microtubes were previously identified with the individual's code, date and site of sample collection, and stored at $-20^{\circ} \mathrm{C}$ until they were analyzed for the species $E$. faecalis, S. warneri and S. aureus, by means of the Checkerboard DNA-DNA hybridization technique ${ }^{18}$ in the Microbiology and Molecular Biology Laboratory of UNG (SP, Brazil).

Sample analyses by the Checkerboard DNA-DNA hybridization technique

The biofilm samples contained in the plastic microtubes were boiled in a bain marie for 10 minutes, and then neutralized by adding $0.8 \mathrm{ml}$ of $5 \mathrm{M}$ ammonia acetate. Each suspension was then deposited in one of the channels of the Minislot 30 (Immunetics, Cambridge, MA, USA) and transferred to the nylon membrane (15 $\mathrm{x}$ $15 \mathrm{~cm}$ ) with a positive charge (Amersham Biosciences UK Limited, Buckinghamshire, England). The last two of the 30 Minislot channels were occupied by controls containing a mixture of the three species being investigated by probes (E. faecalis, S. warneri and S. aureus), at the concentrations corresponding to $10^{5}$ and $10^{6}$ cells; that is, $1 \mathrm{ng}$ and $10 \mathrm{ng}$ of DNA of each species, respectively. The membrane was removed from the Minislot 30 and the DNA concentrated in it was fixed by heating in an oven at $120^{\circ} \mathrm{C}$ for $20 \mathrm{~min}$. Afterwards, the membrane was pre-hybridized at $42^{\circ} \mathrm{C}$, for 1 hour, in a solution containing 50\% formamide (Vetec Química Fina Ltda, Rio de Janeiro, RJ, Brazil); 1\% casein (Vetec), $5 \times$ Saline Sodium Citrate (SSC) $(1 \times$ SSC $=150 \mathrm{mM}$ $\mathrm{NaCl}$ (Vetec); $15 \mathrm{M}$ sodium citrate (J.T.Baker, Edo. de Méx., Mexico), pH 7.0; $25 \mathrm{mM}$ sodium phosphate $\left(\mathrm{Na}_{2} \mathrm{HPO}_{4}\right.$, Labsynth) pH 6.5; and $0.5 \mathrm{mg} / \mathrm{mL}$ yeast RNA (Sigma Aldrich Química Brasil Ltda, São Paulo, SP, Brazil). After this, the membrane was placed in the Miniblotter 45 (Immunetics, Cambridge, MA, USA) with the lines containing the DNA of the sample and controls positioned perpendicularly to the channels of the appliance. In each channel of the Miniblotter 45, a DNA probe was deposited, diluted to approximately $20 \mathrm{ng} / \mathrm{mL}$, in $130 \mathrm{~mL}$ of hybridization solution composed of $45 \%$ formamide; $5 \times$ SSC; $20 \mathrm{mM}$ of $\mathrm{Na}_{2} \mathrm{HPO}_{4}(\mathrm{pH} 6.5) ; 0.2 \mathrm{mg} / \mathrm{ml}$ of yeast RNA; $10 \%$ dextran sulfate (Amersham Biosciences do Brasil LTDA, São Paulo, SP, Brazil) and $1 \%$ casein. Hybridization occurred within a minimum period of 20 hours, at $42^{\circ} \mathrm{C}$.

\section{Detection of the species}

After the hybridization period, the membrane was removed from the Miniblotter 45 (Immunetcs), washed for 40 minutes at $65^{\circ} \mathrm{C}$ in an astringent solution composed of $1 \%$ SDS; $1 \mathrm{mM}$ EDTA and $20 \mathrm{mM} \mathrm{Na} \mathrm{Na}_{2} \mathrm{HPO}_{4}$, for the purpose of removing the probes that had not hybridized completely. After this, the membrane was immersed for 1 hour in a solution containing $1 \%$ maleic acid $\left(\mathrm{C}_{4} \mathrm{H}_{4} \mathrm{O}_{4}\right.$, 
Vetec); $3 \mathrm{M} \mathrm{NaCl} ; 0.2 \mathrm{M} \mathrm{NaOH}$ (Labsynth); 0.3\% Tween 20 (Vetec), $0.5 \%$ casein, $\mathrm{pH} 8.0$, and immediately afterwards, for 30 minutes, in the same solution containing the antidigoxigenin antibody conjugated to alkaline phosphatase (Roche Químicos e Farmacêuticos S. A., São Paulo, SP, Brazil) at a concentration of $1: 10,000$. The membrane was then washed 2 times, for 20 minutes, in a $0.1 \mathrm{M}$ maleic acid solution, $3 \mathrm{M}$ of $\mathrm{NaCL} ; 0.2 \mathrm{M} \mathrm{NaOH} ; 0.3 \%$ Tween $20 ; \mathrm{pH}$ 8.0, and 1 time, for 5 minutes, in a $0.1 \mathrm{M}$ Tris $\mathrm{HCl}$ solution; $0.1 \mathrm{M} \mathrm{NaCl} ; \mathrm{pH} 9.5$.

To detect the signals, the membrane was incubated at $37^{\circ} \mathrm{C}$ for 45 minutes in a detector solution containing substrate for alkaline phosphatase, CDP-Star ${ }^{\mathrm{TM}}$ Detection Reagent (Amersham). After this, the membrane was placed on a Radiographic Chassis $30 \times 40 \mathrm{~cm}$ (Konex, São Paulo, SP, Brazil), with a radiographic film $18 \times 24 \mathrm{~cm}$ (Agfa Gevaert, NV, Belgium) for approximately 40 minutes. The film was later revealed manually by the conventional temperature-time method, in accordance with the manufacturer's instructions (Kodak Brasileira Com. e Ind. Ltda, São José dos Campos, SP, Brazil).

The radiographic films were read by a single trained examiner, calibrated and blind to the clinical group to which the patient belonged. Each signal produced by a certain probe in the plaque sample was compared with the intensity of the signal produced by the same probe in the two lines of controls containing $10^{5}$ and $10^{6}$ bacteria. Thus, the number 0 was recorded when no signal was detected; 1 when there was a less intense signal than that of the control of $10^{5}$ cells, 2 when the signal was similar to that of the control of $10^{5}$ cells; 3 between $10^{5}$ and $10^{6}$ cells; 4 at approximately $10^{6}$ cells and 5 over $10^{6}$ cells (Table 1). These records were use to determine the levels of the different species investigated in the different samples evaluated.

Table 1. Index to determine levels of microorganisms in subgingival biofilm samples. Guarulhos, 2016.

\begin{tabular}{lcc}
\hline Index & Level of microorganism & Count \\
\hline 0 & Not detected & 0 \\
1 & Fewer than $10^{5}$ cells & 10.000 \\
2 & Approximately $10^{5}$ cells & 100.000 \\
3 & Between $10^{5}$ and $10^{6}$ cells & 500.000 \\
4 & Approximately $10^{6}$ cells & 1.000 .000 \\
5 & Over $10^{6}$ cells & 10.000 .000 \\
\hline
\end{tabular}

\section{Statistical analysis}

The microbiological data of the subgingival biofilm samples were expressed in counts (levels) and prevalence of the three bacterial species evaluated. Initially, the mean level and prevalence of each bacterial species per site were computed, subsequently per individual, and later per group. The significant differences between the experimental groups were evaluated by means of the Mann-Whitney test. Statistical significance was established at 5\%.

\section{RESULTS}

All the clinical parameters evaluated were significantly increased in the Periodontitis Group in comparison with the Healthy Group $(p<0.05)$, including mean full mouth PD and CAL, BOP, plaque, GB and SUP.

$A$ higher percentage of the volunteers with periodontitis were colonized by the three species evaluated, in comparison with periodontally healthy individuals $(p<0.05)$. This difference between the two groups was 40 percentage points for $E$. faecalis (present in $90 \%$ of individuals with periodontitis and $50 \%$ in healthy subjects) and S. warneri (100\% and 60\%, respectively); and 26 percentage points for $S$. aureus $(86 \%$ and $60 \%$, respectively) (Table 2). Between 75 and $86 \%$ of the biofilm samples of the volunteers with periodontitis were colonized by the species evaluated, against 18 to $23 \%$ of the samples of healthy volunteers. This difference between the two groups was statistically significant for the three species (Table 3).

Table 2. Percentage of individuals colonized by the species evaluated. Guarulhos, 2016.

\begin{tabular}{lccc}
\hline Pathogens & $\begin{array}{c}\text { Periodontal } \\
\text { health }\end{array}$ & $\begin{array}{c}\text { Chronic } \\
\text { periodontitis }\end{array}$ & p-value \\
\hline & $(\%)$ & $(\%)$ & \\
E.faecalis & 50 & 90 & 0.000 \\
S.aureus & 60 & 86 & 0.001 \\
S.warneri & 60 & 100 & 0.000 \\
\hline
\end{tabular}

Table 3. Mean percentage of sites colonized by the species evaluated. Guarulhos, 2016.

\begin{tabular}{lccc}
\hline Pathogens & Periodontal health & Chronic periodontitis & p-value \\
\hline & $($ Mean \pm SD $)$ & $($ Mean \pm SD $)$ & \\
E.faecalis & $18.3 \pm 3.4$ & $75.1 \pm 5.1$ & 0.0000 \\
S.aureus & $15.1 \pm 2.5$ & $82.1 \pm 3.5$ & 0.0000 \\
S.warneri & $23.3 \pm 5.6$ & $85.9 \pm 2.3$ & 0.0000 \\
\hline SD: standard deviation & & &
\end{tabular}

E. faecalis and S. warneri were present at significantly higher mean levels in individuals with periodontitis than in the healthy individuals $(p<0.05$; 
Figure 1). Although the levels of $S$. aureus were also lower in healthy individuals, this difference between the two groups was not statistically significant $(p>0.05)$.

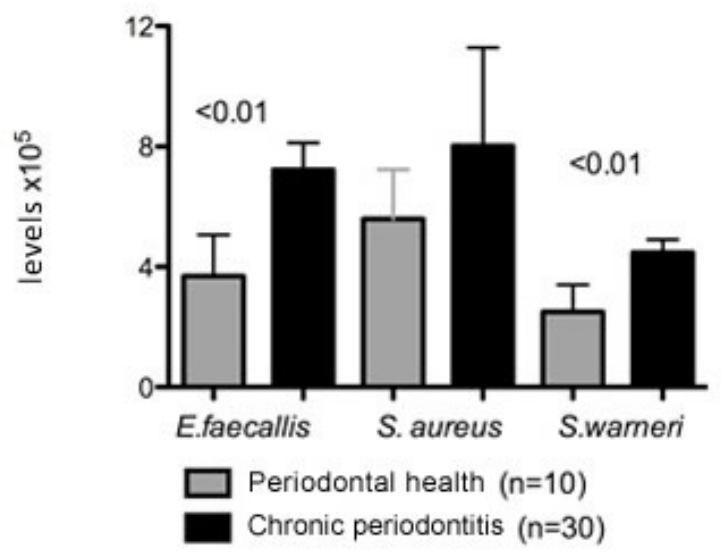

Figure 1. Levels $\left(x 10^{5}\right)$ of the species evaluated in healthy individuals with chronic periodontitis. Guarulhos,2016.

In the analyses per category of sites, we observed that the shallow (PD $\leq 4 \mathrm{~mm}$ ) and deep (PD $\geq 5 \mathrm{~mm}$ ) sites of volunteers with periodontal disease presented higher mean counts $\left(\mathrm{X} 10^{5}\right)$ of $S$. warneri than those of periodontally healthy volunteers ( $p<0.05$; Figure 2 ). In relation to $E$. faecalis and $S$. aureus, this difference was only significant between the deep sites of volunteers with disease and those of healthy individuals $(p<0.05)$.

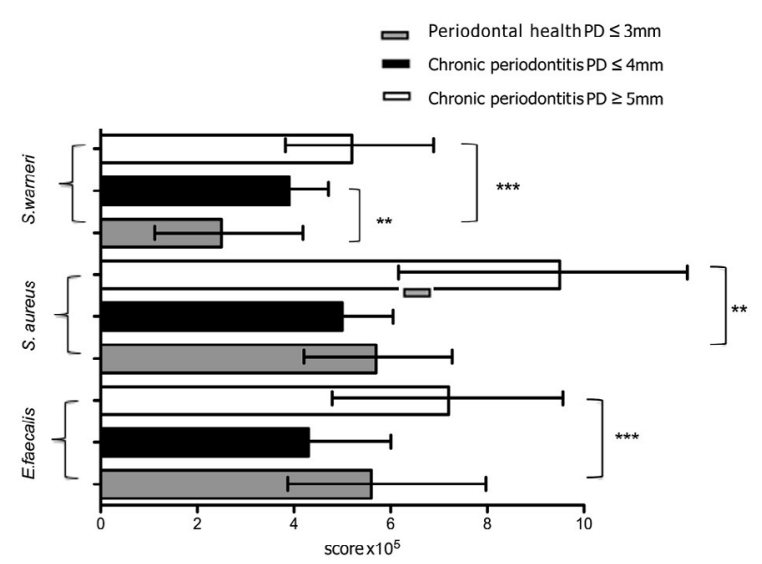

Figure 2. Pathogens levels by site category in healthy individuals with chronic periodontitis. Guarulhos, 2016

\section{DISCUSSION}

Of the five parameters evaluated in the present study [(i) percentage of individuals colonized, (ii) percentage of sites colonized, (iii) levels of species in the samples, (iv) levels of species in the samples in shallow pockets, e (v) levels of species in the samples in deep pockets], $S$. warneri was increased in the volunteers with periodontitis in comparison with periodontally healthy individuals in the five parameters; $E$. faecalis in four and $S$. aureus in three parameters.

In spite of approximately half of the periodontally healthy subjects presenting at least one site colonized by one of the three suspected periodontal pathogens evaluated in this study, the levels of $E$. faecalis and $S$. warneri were significantly reduced in these individuals, in comparison with those who presented the disease. Moreover, higher levels of $S$. warneri were identified in shallow sites of volunteers with disease, in comparison with healthy individuals. This are important data, because a continuous debate in periodontal literature has posed the question asking whether the higher quantity of periodontal pathogens in deep pockets would result only from an overgrowth of these species, favored by the environmental conditions of the periodontal pocket ${ }^{10}$. However, the presence of possible periodontal pathogens in higher levels even in shallow sites of patients with disease contradicted this theory, and constituted an indication of a causal relationship between the presence of the microorganism and onset of infection. A joint evaluation of these data suggested greater evidence that $S$. warneri played a role in the etiology of periodontitis, followed by E. faecalis. Whereas in the case of $S$. aureus, in spite of being present in a higher percentage of diseased than healthy individuals, their mean levels did not differ significantly between the two groups, which in some way reduced the possibility of this bacterial species being considered a true periodontal pathogen.

Previous studies have also observed some association of the bacterial species $E$. faecalis ${ }^{19}, S$. warneri14,19-22, and $S$. aureus ${ }^{23-24}$ with periodontal diseases. Furthermore, a recent systematic review by our research group $^{10}$ that evaluated the weight of evidence of the existence of new periodontal pathogens suggested that 32 new strains might be associated with the etiology of periodontal diseases. It was proposed that there was moderate evidence relative to the role of the bacterial species E. faecalis as a periodontal pathogen. Souto \& Colombo ${ }^{25}$ studied the prevalence of $E$. faecalis in subgingival biofilm and saliva samples from individuals with chronic periodontitis and periodontally healthy individuals. Positive correlations were observed between the presence of $E$. faecalis and clinical parameters of PD, CAL, BOP and biofilm 
accumulation. Recently, Murad et al. ${ }^{19}$ also observed that E. faecalis together with S. warneri were part of the most prevalent bacterial species of the microbiota of root canals associated with endodontic treatment failure, and that $E$. faecalis could play an important role in chronic periapical lesions. The authors also found a positive correlation between the counts/frequency of $E$. faecalis and the mean $\mathrm{PD}$, data similar to those of the present study, in which we observed E. faecalis at higher levels in periodontal disease, but in higher quantities in deep than in moderate sites. This could be an indication of the association of this bacterial species with periodontal diseases progression.

Whereas, S. warneri was identified by means of genetic sequencing in individuals who did not respond well to periodontal therapy (previously called "refractory periodontitis" $)^{21}$. Contrary to other types of staphylococcus, S. warneri has been found in elevated quantities in implants in function for 10 years and showed positive correlation with peri-implant inflammation ${ }^{14}$. This coagulase-negative species is known to colonize orthopedic implants ${ }^{20}$, cause recurrent infection in cases of aortic prostheses ${ }^{22}$, and in the oral cavity, it is known to be one of the most prevalent bacterial species in persistent root infections ${ }^{19}$.

In relation to the bacterial species $S$. aureus, Heller et al. ${ }^{26}$ observed that it was one of the most predominant species in individuals with chronic periodontitis. Later, in agreement with the data of the present study, Colombo et al. ${ }^{24}$ detected $S$. aureus in high quantities in periodontally healthy individuals when compared with patients with aggressive periodontitis, however, without statistical difference in comparison with individuals with chronic periodontitis. In general terms, $S$. aureus produces a large variety of toxins, and is an important medical pathogen because it is one of the main etiological agents of respiratory infections ${ }^{27}$ and presents extensive antimicrobial resistance ${ }^{19}$. In the oral cavity, S. aureus has mainly been related to endodontic infection $\mathrm{s}^{28}$ and has been suggested as a possible peri-implant pathogen ${ }^{23}$. However, its role in chronic periodontitis has not yet been well defined.

\section{REFERENCES}

1. Socransky SS, Smith C, Martin L, Paster BJ, Dewhirst FE, Levin AE. "Checkerboard" DNA-DNA hybridization. Biotechniques. 1994;17:788-792.

2. Socransky SS, Haffajee AD, Smith C, Martin L, Haffajee JA, Uzel NG, Goodson JM. Use of checkerboard DNA-DNA hybridization to study complex microbial ecosystems. Oral Microbiol Immunol. 2004 Dec;19(6):352-62.
The study of possible "novel periodontal pathogens" is an important point for better understanding of the etiology of periodontal disease, and consequently, for establishing more targeted therapies considering, for example, that the three species studied are facultative anaerobes ${ }^{24}$. Association studies, such as the one here described, is the first step towards understanding novel species within the complex interaction of dental biofilm ${ }^{29}$. The large quantity of samples processed and the analysis performed by categories of periodontal sites are strong points to be considered in this study. However, elimination analyses, host response and mechanisms of pathogenicity need to be done to obtain a definitive conclusion about the real role of S. warneri, E. faecalis and S. aureus in the onset and progression of periodontal diseases ${ }^{30}$.

\section{CONCLUSION}

E. faecalis and particularly S. warneri have the potential to be periodontal pathogens. The role of $S$. aureus was less evident, because this species was more prevalent and at relatively higher levels in healthy individuals, than the other two species. These data may guide future studies about the role of these microorganisms in the etiology of periodontitis and help to establish more effective treatments for these infections.

\section{Collaborators}

A FRITOLI was responsible for processing the microbiological samples. E LOBÃO participated in the collection and processing of the samples. GMS SOARES and B RETAMAL-VALDES were responsible for the standardization of the DNA probes. M FERES designed the study and conducted the data analysis. She was also the study coordinator. SCL MONTENEGRO and all the other authors participated in the development of this manuscript.

3. Socransky SS, Haffajee AD, Cugini MA, Smith C, Kent RL, Jr. Microbial complexes in subgingival plaque. J Clin Periodontol. 1998;25:134-144

4. Consensus report. Periodontal diseases: pathogenesis and microbial factors. Ann Periodontol. 1996;1:926-932.

5. Paster BJ, Boches SK, Galvin JL, et al. Bacterial diversity in human subgingival plaque. J Bacteriol. 2001;183(2):3770-83. doi: 10.1128/JB.183.12.3770-3783.2001 
6. Kumar PS, Griffen AL, Moeschberger ML, Leys EJ. Identification of candidate periodontal pathogens and beneficial species by quantitative $16 \mathrm{~S}$ clonal analysis. J Clin Microbiol. 2005;43(8):3944-55.

7. Dahlen G, Leonhardt A. A new checkerboard panel for testing bacterial markers in periodontal disease. Oral Microbiol Immunol. 2006;21(1):6-11. doi: 10.1111/j.1399-302X.2005.00243.x

8. Faveri M, Mayer MP, Feres M, de Figueiredo LC, Dewhirst FE, Paster BJ. Microbiological diversity of generalized aggressive periodontitis by $16 \mathrm{~S}$ rRNA clonal analysis. Oral Microbiol Immunol. 2008;23(2):112-8. doi: 10.1111/j.1399-302X.2007.00397.x.

9. Colombo AP, Boches SK, Cotton SL, Goodson JM, Kent R, Haffajee $A D$, et al. Comparisons of subgingival microbial profiles of refractory periodontitis, severe periodontitis, and periodontal health using the human oral microbe identification microarray. J Periodontol. 2009;80(9):1421-1432. doi: 10.1902/ jop.2009.090185

10. Pérez-Chaparro PJ, Gonçalves C, Figueiredo LC, Faveri M, Lobão E, Tamashiro N, et al. Newly identified pathogens associated with periodontitis: a systematic review. J Dent Res. 2014;93(9):1-13. doi: $10.1177 / 0022034514542468$

11. Socransky SS, Haffajee AD. Periodontal microbial ecology. Periodontol 2000. 2005;38:135-187. doi: 10.1111/j.16000757.2005.00107.x

12. Colombo API, Teles RP, Torres MC, Sauto R, Rosalém WJ, Mendes $M C$, et al. Subgingival Microbiota of Brazilian subjects with untreated chronic periodontitis. J Periodontol. 2002;73(4):3609. doi:10.1902/jop.2002.73.4.360

13. Souto R, Colombo Ap. Prevalence of Enterococcus faecalis in subgingival biofilm and saliva of subjects with chronic periodontal infection. Arch Oral Biol. 2008;53(2):155-60. doi: 10.1016/j.archoralbio.2007.08.004

14. Eick S, Ramseier CA, Rothenberger K, Bragger U, Buser D, Salvi GE. Microbiota at teeth and implants in partially endentulous patients. A 10-year retrospectivr study. Clin Oral Implants Res. 2016 Feb;27(2):218-25. doi:10.1111/clr.12588.

15. 1999 International Workshop for a Classification of Periodontal Disease and Conditions. Ann of Periodontol. 1999;4(1):1-12.

16. Matarazzo F, Figueiredo LC, Cruz SE, Faveri M, Feres M. Clinical and microbiological benefits of systemic metronidazole and amoxicillin in the treatment of smokers with chronic periodontitis: a randomized placebo-controlled study. J Clin Periodontol. 2008 Oct;35(10):885-96. doi: 10.1111/j.1600-051X.2008.01304.x

17. Lang NP, Tonetti MS. Periodontal risk assessment (PRA) for patients in supportive periodontal therapy (SPT). Oral Health Prev Dent. 2003;1(1):7-16

18. Haffajee AD, Socransky SS, Goodson JM. Comparison of different data analyses for detecting changes in attachment level. J Clin Periodontol. 1983;10(3):298-310. doi: 10.1111/j.1600051X.1983.tb01278.x
19. Murad CF, Sassone LM, Faveri M, Hirata R Jr, Figueiredo L, Feres M. Microbial diversity in persistent root canal infections investigated by checkerboard DNA-DNA hybridization. J Endod. 2014;40(7):899-906. doi: 10.1016/j.joen.2014.02.010

20. Arciola $C R$, Campoccia D, An YH, Baldassarri L, Pirini V, Donati $\mathrm{ME}$, et al. Prevalence and antibiotic resistance of 15 minor staphylococcal species colonizing orthopedic implants. Int J Artif Organs. 2006;29(4):395-401.

21. Colombo AP, Haffajee AD, Dewhirst FE, Paster BJ, Smith $C M$, Cugini MA, et al. Clinical and microbiological features of refractory periodontitis subjects. J Clin Periodontol. 1998;25(2):169-80. doi: 10.1111/j.1600-051X.1998.tb02424.x

22. Arslan F, Saltoglu N, Mete B, Mert A. Recurrent Staphylococcus warnerii prosthetic valve endocarditis: a case report and review. Ann Clin Microbiol Antimicrob. 2011 23;10:14. doi: 10.1186/1476-0711-10-14

23. Persson GR, Renvert S. Cluster of bacteria associated with periimplantitis. Clin Implant Dent Relat Res. 2014;16(6):783-93. doi: 10.1111/cid.12052

24. Colombo APV, Magalhães CB, Hartenbach FARR, Souto RM, Silva-Boghossian CM. Periodontal-disease associated biofilm: a reservoir for pathogens of medical importance. Microb Pathog. 2015; 94:27-34. doi: 10.1016/j.micpath.2015.09.009

25. Souto R, Colombo AP. Prevalence of Enterococcus faecalis in subgingival biofilm and saliva of subjects with chronic periodontal infection. Arch Oral Biol. 2008;53(2):155-60. doi: 10.1016/j.archoralbio.2007.08.004

26. Heller D, Silva-Boghossian CM, do Souto RM, Colombo AP. Subgingival microbial profiles of generalized aggressive and chronic periodontal diseases. Arch Oral Biol. 2012;57(7):973-80. doi: 10.1016/j.archoralbio.2012.02.003

27. Valour F, Chebib N, Gillet Y, Reix P, Laurent F, Chidiac C, et al. Staphylococcus aureus broncho-pulmonary infections. Rev Pneumol Clin. 2013;69(6):368-82. doi: 10.1016/j. pneumo.2013.08.004

28. Wyman TP, Dowden WE, Langeland K. Staphylococcus aureus isolation from a clinically nonexposed root canal. J Endod. 1978;4(4):122-8. doi: 10.1016/S0099-2399(78)80202-7

29. Socransky SS, Haffajee AD. Dental biofilms: difficult therapeutic targets. Periodontol 2000. 2002;28(1):12-55. doi: 10.1034/j.1600-0757.2002.280102.x

30. Socransky SS. Criteria for the infectious agents in dental caries and periodontal disease. J Clin Periodontol. 1979;6(7):16-21. doi: 10.1111/j.1600-051X.1979.tb02114.x

Received on: 24/3/2016 Final version resubmitted on: 30/9/2016 Approved on: 6/1/2017 